AGRARIS: Journal of Agribusiness and Rural Development Research

Vol. 6 No. 1 January-June 2020

Article History:

Submitted : June $27^{\text {th }}, 2019$

Accepted : March $26^{\text {th }}, 2020$
Dina Nurul Fitria ${ }^{1}$, Harianto², D S Priyarsono2, Noer Azam Achsani ${ }^{2}$

${ }^{1}$ Faculty of Economics and Business, Universitas Pertamina, Indonesia

${ }^{2}$ Faculty of Economics and Management, Institut Pertanian Bogor, Indonesia

\title{
Asymmetric Price Transmission with Threshold Behavior of Potatoes Market in Bandung Regency West Java
}

\author{
DOI: https://doi.org/10.18196/agr.6193
}

\begin{abstract}
Horticulture products price in Indonesia (for certain commodities) has experienced the issue of volatility, price decline at farm gate stage, due to oversupply is not equal to or comparable with price high at the other stage. This paper endeavors to investigate threshold behavior in asymmetry test by taking the case of potatoes prices in two important state levels of price, i.e. farm gate prices, and retail prices. The observation used monthly price data from January 2009 to December 2013. Threshold behavior detected by TAR model that fits in asymmetry testing with two regimes. Threshold value is interpreted as a measure of transaction cost between retail to farm gate and high the quantity supplied, that would create incentive for trade. Research results reveals as per monthly data price adjustment between farm gate to retail not presence of asymmetry price transmission. Asymmetry only reveals within seasonal data, threshold behavior forms margins overshoot of potatoes equilibrium trader's levels, thus leading to farmer's decision in profit maximization.
\end{abstract}

Keywords: price asymmetry, potatoes, threshold behavior, TAR Model

\section{INTRODUCTION}

Horticulture as part of the agricultural sector holds potential for consumption and production that needs to be developed, considering that many varieties of fruits, vegetables, biopharmaceuticals and ornamental plants are endemic to Indonesia and become economic commodities with high added value.

Based on the preliminary survey in Desa Pringgowijayan Kutoarjo on March 15 to 18, 2013, horticultural household farming implements rotational cropping or intercropping with food crops. Thus, decision making process in planting, harvesting, and marketing, heavily dependent on: (1) input prices of food crops and (2) equilibrium price established at the farm level generates equilibrium price at the wholesale/collectors to determine price supply at retails, (3) the high costs of farming horticulture compensated by planting intercropping food crops, as example, in one plot contained tomato plant, red chili, maize and other cash crops.

Conceptually, the perfectly competitive market for each actor assumed to have all the information about the price determined by a state of balance between supply and demand. 
Empirical findings in red chili competitive market that price spread causes an equilibrium price gap established at the farm level, wholesale/collector level and retail (Fitria et al, 2019). Figure 1 shown there is also an equilibrium price gap in potatoes competitive market.

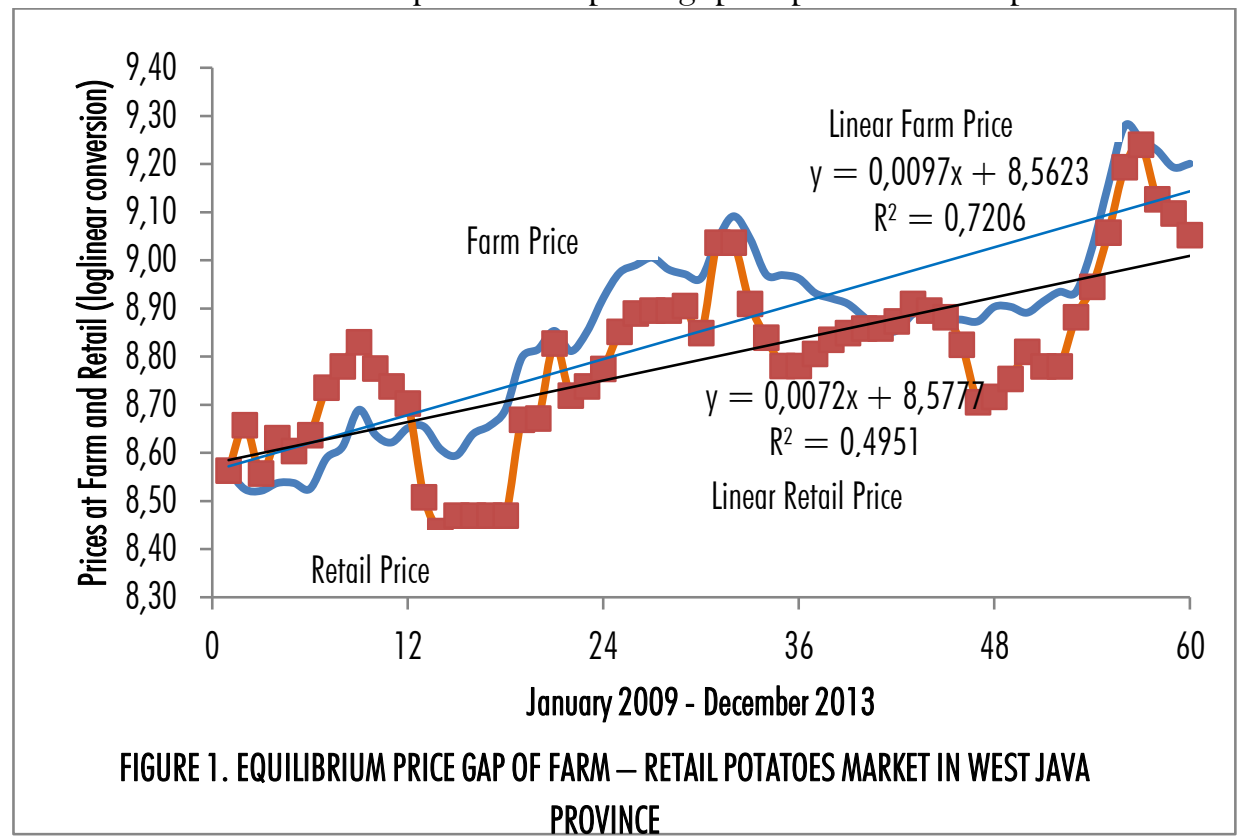

Source: Statistics Indonesia, Bandung Regency (2014)

Potatoes market price fluctuations increase at farm level in October 2011 to October 2013. The fluctuation in farm level of price goes beyond to increase at the retail level over the same period. Due to high demand, potatoes planted in the Bandung regency are Granola and Atlantic varieties. Granola potatoes are cultivated by farmers independently with marketing chains through collecting-merchants deliver to wholesale in Bandung cities for various retail markets, i.e. wholesales market and the traditional market and supermarket market.

In the meantime, Atlantic potatoes are cultivated by farmers through a business partnership in this case is marketing with PT Indofood FM through the facilitation of traders or the group of farmers, farmers prefer to plant Granola potatoes because the price received is quite high compared to growing Atlantic potatoes. The price received by potatoes farmers reflects the high in farming costs, including the price of pesticides, fertilizer prices and wage. The price of imported potatoes does not affect the price of local potatoes (Andriyanto et al, 2013). On the post-harvest side, the high retail price of potatoes reflects the growing demand for potato consumption of local potatoes.

Price transmission can occur in the form of high or low in prices, where every one percent change in price on a farm is always assumed to be a symmetrical form of price transmission. The response that occurs in the retail market to high price is faster than the response that occurs in the retail market to low price. The price changes that is responded by the retail market, especially for agricultural commodities that are 'perishable', is determined by market concentration in the structure of perfectly competitive and segmented markets (monopolistic competition markets) and the storage capacity of 'perishable' products (Aguiar and Santana, 2002). 
High or low price of horticultural commodities that occur at the level of retailers, is not always followed by a high or low price at the farmers level, this affects the transmission level of different prices due to regional conditions (spatial transmission), which bring up the transaction costs. In this case transportation costs and choice of farming input factors that pose price risks due to quality (results of previous research in Pangalengan and Lembang District on 11 July - 3 August 2014).

Meanwhile, horticultural commodity prices are relatively affected by domestic supply and demand rather than world prices, because of market imperfections due to imperfections of information and distribution issues, so that world prices are not directly transmitted to farm regions. There are several price transmission issues about potatoes commodities at the farm level and at the trader level.

Empirically there are two price formation events, the first is when the agreement of the actual purchase price agreement from farmers with the expectation of selling prices by collector traders. The second is the transmission of farm costs at the farmer level and the transmission of marketing costs at the level of retail traders which is the trading system margin and profit received by the traders.

This article describes the problem of horticultural price fluctuations received by farmers and price fluctuations at the retail level through the mechanism of potatoes price transmission and threshold behavior using the Markov switching concept. The markov switching concept is generally used in the research of option prices for asset-that has stochastic volatility serial data (Hull and White, 1987). Likewise, agricultural commodity prices have stochastic volatility data series at different market power, namely oligopsony at the trader level, while at the farm level the perfect competitive market forces apply (Siregar, 2012).

\section{METHODOLOGY}

Data

The data used in this research are time series data from the period of January 2009 to December 2013 consisting of monthly price data of potatoes at the Farmers level in Pengalengan sub-District, Bandung district and retailers in Bandung City. The data source is the publication of Agriculture Farm Price Statistics for Horticultural Crops Sector in the period of 2009-2013 per month.

When a sample of price data in farmer level and retail level is found to be incomplete, data sources from the Directorate General of Horticulture, the West Java Provincial Agriculture Office, Bandung District and Caringin Market are also used. Caringin wholesales market was chosen because collectors/dealers who are members of the Caringin market cooperative have a 'note' purchase order system to farmers to ensure the availability of supplies to be sold. These diverse data sources make up 60 observational data.

\section{Method}

Research method uses an error correction (ECM) and cointegration model estimated from the movement of potatoes price data at the farm level (FP) and at the retail level (IDR) 
to test the asymmetrical alleged vertical price transmission. The substance of the ECM model is testing the error significance of the long-term equilibrium model through cointegration tests on two series of potatoes price data at the farm and at the retail level.

When there is no cointegration, the ECM model does not use the Von Cramon and Loy models to obtain sources of asymmetrical price transmission, but the Houck and other models are used (Wixson and Katchova, 2012). In estimating the ECM model, we need to know the lag length of $c_{1}, c_{2}$, and so on. The length of the lag is statistically different from zero. If the lag length is not the same, then the AIC (Akaike Information Criterion) test or SIC (Schwartz Information Criterion) test is used to select the ECM model or the Houck model.

Cointegration test results and lag length, are produce short-term equilibrium adjustment parameters that are reflected in the error coefficient cointegrating term $\left(\mathrm{ECT}_{\mathrm{t}-1}\right)$ and farm-level price parameters of the ECM model (von Cramon-Taubadel and Fahlbusch, 1996).

The positive or negative sign of the ECT reflects the formation of the balance price above the balance line or below the balance line. In the context of vertical price transmission in a marketing chain, asymmetric price transmission of positive or negative values does not only exist from the level of farm prices to the level of retail prices, but can also occur vice versa from the level of retail prices to the level of farm prices (Boyd and Brorsen, 1988).

When cointegration testing and lag length established, the next test is the presence or absence of structural breaks and the presence or absence of threshold behavior using a nonlinear model to obtain corrected long-term equilibrium price behavior. One of the known nonlinear models is the threshold autoregression model at $\mathrm{c}=1$ referred to as regime 1 and $\mathrm{c}$ $=2$ referred to as regime 2 . The expected test results are a decision that there is no structural break and there is a shift in the price regime in price behavior threshold with the Markov Regime Switching testing model introduced by Hamilton (1989 and 1990).

The asymmetry of positive price transmission is a condition of faster and/or more perfect price movements that occurs when there is squeeze margin high at the farmer's price level or a low at the retail price level, compared to when there is a high in the margin at the farmer's price low or price highs at the retail level.

Operational model equations of the asymmetry of the transmission of potatoes commodity prices were tested through a series of tests namely data stationarity test, cointegration test, sources of asymmetry of price transmission along with their effects with the wald test, threshold behavior test on the ECM von Cramon-Taubadel and Loy models below. $\Delta \mathrm{RP}_{\text {it }}=\alpha+\beta_{1}{ }^{-} \Delta \mathrm{FP}_{\mathrm{it}}{ }^{-}+\beta_{1}{ }^{+} \Delta \mathrm{FP}_{\mathrm{it}}{ }^{+}$

note that,

$\Delta \mathrm{RPit}$, changes of potatoes price at the retail level when it.

$\Delta \mathrm{FPit}^{-}$, changes of potatoes price of at the farm level when price low.

$\Delta \mathrm{PFt}^{+}$, changes of potatoes price at the farm level when price high.

$\beta, \beta^{+}$, asymmetry coefficient of price transmission, if statistically significant, the values of $\beta, \beta^{+}$ are not identical. 
In estimating the ECM model, we need to know the length of the lags, statistically different values from zero. The ECM asymmetry process is statistically significant on the Houck model. When the lag length is not the same, then AIC (Akaike,1974) or SIC (Schwartz, 1978 ) is used to choose between Houck or ECM model specifications.

$\Delta \mathrm{RP}=\alpha+\beta_{2} \Delta \mathrm{FP}+\mathrm{cECT}_{(\mathrm{t}-1)}$

$\Delta \mathrm{RP}$, changes of potatoes price at the retail level.

$\beta_{2} \Delta \mathrm{FP}$, coefficient changes of potatoes price at the farm level.

$\mathrm{cECT}_{(\mathrm{t}-1)}$, coefficient variable of equilibrium adjusted price in the short term.

For price transmission asymmetry test that sourced from structural break refers to equation (2) operates switching model to see if there is any effect of price balance adjustment in the long run.

$$
\begin{aligned}
\Delta \mathrm{FP}_{\mathrm{t}} & =\alpha^{1}+\sum_{j=1}^{K}\left(\beta_{j}^{1} \Delta R P_{t-j+1}\right)+\phi^{1} E C T_{t-1}+\gamma_{\mathrm{t}} \text { if } \mathrm{ECT}_{\mathrm{t}-1}<\mathrm{c}_{1} \\
& =\alpha^{2}+\sum_{j=1}^{K}\left(\beta_{j}^{2} \Delta P_{t-j+1}^{R}\right)+\phi^{2} E C T_{t-1}+\gamma_{\mathrm{t}} \text { if } \mathrm{ECT}_{\mathrm{t}-1} \leq \mathrm{c}_{2} \\
& =\alpha^{3}+\sum_{j=1}^{K}\left(\beta_{j}^{3} \Delta P_{t-j+1}^{R}\right)+\phi^{3} E C T_{t-1}+\gamma_{\mathrm{t}} \quad \text { if } \mathrm{ECT}_{\mathrm{t}-1}>\mathrm{c}_{2}
\end{aligned}
$$

One of the main advantages of TAR is its ability to capture the price asymmetry of transmission in the long term price balance. The expected results of this analysis are (a) the size and speed of transmission of prices from the farmer level, and retail and vice versa, (b) sources of asymmetry of price transmission namely market power, farm transaction costs for potatoes commodities, (c) transmission elasticity prices that can indicate the market power of selected horticultural commodities.

The probability transition with Markov switching process consists of transitioning random variables that cannot be observed zt from regime 1 to regime 2 or regime 2 to regime 1 , which is the probability of the following zt.

$\operatorname{Prob}[z \mathrm{t}=1 \mid \mathrm{zt}-1=1]=\mathrm{P}_{11}$

$\operatorname{Prob}[z \mathrm{t}=2 \mid z \mathrm{t}-1=1]=1-\mathrm{P}_{11}$

$\operatorname{Prob}[z \mathrm{t}=2 \mid z \mathrm{t}-1=2]=\mathrm{P}_{22}$

$\operatorname{Prob}[z \mathrm{t}=1 \mid z \mathrm{t}-1=2]=1-\mathrm{P}_{22}$

The numbers of the probability of subsequent turnover of the regime are calculated, e.g. obtained by parameter coefficient $\mathrm{P}_{11}$, then the expected price dropped at the regime of 1 of the parameter coefficient $\mathrm{P}_{11}$, followed by expected price of up to $\mathrm{P}_{12}$ by $1-\mathrm{P}_{11}$. So, the average length of time for farmer's price and retail price decreased is $1 / \mathrm{P}_{12}$ units/week (depending on the actual serial data unit) or can also be said that the retail price raises every $1 / \mathrm{P}_{12}$

\section{RESULT AND DISCUSSION}

A commodity potato is one of the leading horticultural commodities in West Java (Department of Agriculture Crops, 2006). Types of potatoes that are widely cultivated by farmers in Bandung Regency are Granola potatoes and farmers who collaborate with PT Indofood FM through the mediation of farmer groups working on Atlantic potatoes. The average of potatoes cultivation is between 0.5 to 1.5 hectares. Potatoes production centers in West Java are in the highlands which are concentrated in several districts namely Bandung, 
Garut, Majalengka, and Cianjur. The distribution of production centers is quite high, namely in Bandung Regency mainly in Pengalengan, Ciwidey, and Lembang Districts with diverse marketing patterns for the purpose of the wholesale market, traditional markets, supermarkets and processing industries (PT. Indofood Fritolay Makmur) (Agustian and Mayrowani, 2008).

The price of potatoes in the January 2009 to December 2013 period at the farmer level was the most varied. Table 1 informs that the potato commodity has a monthly average farmer's price of IDR 6,820 and a farm-level price distribution of IDR 1,340. The coefficient of variation in farm-level prices is 19.7 , so the diversity of farm-level prices increasingly varies at a minimum price of IDR 4,770 and a maximum price of IDR 10,411. Potatoes prices at the average monthly retail level of IDR 7,060 and a price distribution of IDR 1,342.

The retail price of potatoes has a coefficient of variation of 19.0 has a homogeneous distribution representing the population of retail price data in the range of a minimum monthly retail price of IDR 4,620 and a monthly maximum of IDR 10,714. This also shows that the price of potatoes at the producer level changes more quickly than retail prices.

TABLE 1. POTATOES PRICE STATISTIC DESCRIPTIVE AT FARM AND RETAIL BY JANUARY 2009 TO DECEMBER 2013 IN BANDUNG REGENCY (IN RUPIAHS)

\begin{tabular}{lccccc}
\hline Variables & Average & Standard of Deviation & Minimum & Maximum & Variance \\
\hline Farm Price & 6,820 & 1,340 & 4,770 & 10,411 & 19.7 \\
Retail Price & 7,060 & 1,342 & 4,620 & 10,714 & 19.0 \\
\hline
\end{tabular}

Source: Bandung Regency Statistical Office (2014), calculated.

\section{Stationarity Test}

Model tested stationary with Augmented Dicky Fuller (ADF) test in 5\% level of significance. If, ADF test results lower than Mackinon critical value, then data is stationery condition. Stationarity test explained in Table 2.

TABLE 2. STATIONARITY TEST RESULT ON FARM - RETAIL PRICES BY JANUARY 2009 TO DECEMBER 2013 WITH INTERCEPT IN BANDUNG REGENCY

\begin{tabular}{lcc}
\hline \multirow{2}{*}{ Variables } & \multicolumn{2}{c}{ ADF Value in 5\% level of significance } \\
\cline { 2 - 3 } & Level & First Difference \\
\hline Farm Price & -1.297 & $-5.355^{*}$ \\
Retail Price & 1.577 & $-6.622^{*}$ \\
\hline
\end{tabular}

Source: Authors' Calculation

Data stationarity testing is conducted in two ways, farmer price as the dependent variable and retail price as the dependent variable. Test is carried out at the level (the original data) with intercept. The results of this stationarity test can be seen from the probability, if it is above $5 \%$, then the data contains a unit root or not stationary. Potatoes commodity data has been stationary at first difference. If testing the data, at the retail price and farmer level is not stationary at the level, it indicates co-integration on both variables thus there is a longterm balance.

\section{Causality Test}

The difference of price transmission effect from price changes at farm and retail found with Granger Causality test. Both farm and retail price variables treated as dependent or independent factor as well. 
TABLE 3. GRANGER CAUSALITY TEST RESULT ON POTATOES PRICES AT FARM AND RETAIL BY JANUARY 2009 TO DECEMBER 2013 IN BANDUNG REGENCY

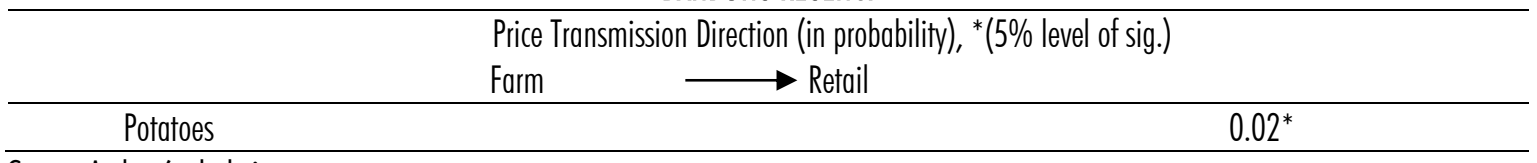

Source: Authors' calculation

The causality test results potatoes commodity price transmission indicates a one-way direction between farmers' price and retail price. The price changes initiated at the farmer level has direct effect on potatoes demand at the retail level. Thus, the price of potatoes commodity at retail established in price change at the farmer level.

\section{Co-integration Test}

Co-integration test results determine the long-term balance, which is useful for identifying the value of high-price adjustments $\left(\mathrm{ECT}^{+}\right)$above the balance line and low-price adjustments $\left(\mathrm{ECT}^{-}\right)$below the balance line. In the long-term equilibrium correction model, the price of potatoes at the level obtained is stationary with a probability of 0.01 indicating the price of potatoes at the farm level and at the co-integrated retail level, it is long-term equilibrium.

Once it is known that the price of potatoes at the farm level and the price of potatoes at the retail level occur in a long-term balance, it is necessary to test the adjustment of price up and high or asymmetric or asymmetrical price. If it is proven that a significant price adjustment has an effect on the price balance correction model, there is an asymmetry of dynamic price transmission (Von Cramon and Loy, 1999). The price adjustment coefficient test $\left(\mathrm{ECT}_{\mathrm{t}-1}\right)$ results at -0.21 with the Von Cramon dynamic long-term balance correction (ECM) model is significant at probability 0.01 .

\section{Asymmetric Test with Threshold Model}

Price symmetry testing is carried out to determine the transmission price of potatoes at the Farmer level to the retail price of potato in Bandung City perfectly. Von CramonTaubadel and Loy's dynamic model separates the asymmetrical price transmission between short-term transmission and long-term transmission. The asymmetry of price transmission indicates that there is a threshold behavior that reflects the value of transaction costs and marketing margins (Sherman and Weiss, 2012).

As presented in Table 4, the movement in the direction of transmission of potatoes prices from the farmer level to the retail price is 1.02 and the speed of price adjustment increases at the retail level by -0.29 . The negative sign on the coefficient of adjustment of $\mathrm{ECT}_{\mathrm{t}-1}^{+}$price movements $\mathrm{t}-1$ indicates that the speed of the price adjustment increases takes place through a short-term correction from the farmer level transmitted to the retail price of magnitude 0.29 , at the significance level $<10 \%$ probability value.

The price adjustment coefficient goes up $\mathrm{ECT}_{\mathrm{t}-1}^{+}$and the price balance coefficient in the short term is negative and It means that there is a threshold correction when the price adjustment goes up $\mathrm{ECT}_{\mathrm{t}-1}^{+}$on the balance line on the short term $\mathrm{ECT}_{\mathrm{t}-1}$. At the time the price 
increases at the farmer level, price correction occurs, and it is transmitted at a long-term increase in the balance price at the retail level.

TABLE 4. ASYMMETRIC PRICE TRANSMISSION TEST RESULT AT FARM AND RETAIL BY JANUARY 2009 TO DECEMBER 2013, BANDUNG REGENCY

\begin{tabular}{lcc}
\hline Variables & Coefficient & Probability $(10 \%)$ \\
\hline$\Delta \mathrm{FP}$ & 1.02 & 0.0000 \\
$E \mathrm{CT}^{+}+1-$ & -0.29 & 0.0623 \\
$E \mathrm{~T}_{\mathrm{H}-1}$ & -0.14 & 0.3801 \\
$\mathrm{R}^{2}$ & & 0.4370 \\
F test & & 14.2287 \\
Prob(F test) & & 0.0000 \\
DW & & 1.9114 \\
\hline
\end{tabular}

Source: Authors' calculation

The price adjustment coefficient goes up $\mathrm{ECT}_{\mathrm{t}-1}^{+}$and the price balance coefficient in the short term $\mathrm{ECT}_{\mathrm{t}-1}$ is negative. If there is a threshold correction, then the price adjustment goes up $\mathrm{ECT}_{\mathrm{t}-1}^{+}$on the balance line on the short term $\mathrm{ECT}_{\mathrm{t}-1}$. When prices increase at the farm level, price corrections transmitted to long-term equilibrium price increases at the retail level.

If the $\mathrm{ECT}_{\mathrm{t}-1}$ is not significant at a probability value $>10 \%$, then the correction below the balance line has no effect on changes in potato prices at the retail level. In the potato commodity, the $\mathrm{ECT}_{\mathrm{t}-1}$ of -0.14 is not significant so there is no correction in the short term, i.e. the price drops at the farm level there is a correction below the balance line which affects the adjustment back to the long-term balance of magnitude 0.14 when prices decrease at the retail level.

So that the decline in potato prices at the farm level does not affect the decline in prices at the retail level. The price of potatoes increases at the farm level has an influence on the increase of potato prices at the retail level and is transmitted faster than when prices decrease at the farm level. There is a common response due to price changes that occur at the farm level to the formation of potato prices at the retail level when prices decrease or increase.

Asymmetric increase in potato prices by $1 \%$ at the retail level has an effect of $77.52 \%$ increase in prices at the farm level in the short term. Asymmetrical changes in one direction are positive, reflecting the elasticity of price transmission that is inelastic to the commodity potatoes at the farm level $\left(\Delta \mathrm{PF}_{\mathrm{t}}^{+}\right)$.

The $\mathrm{ECT}_{\mathrm{t}-1}$ of -0.14 is not significant so there is no correction in the short term, i.e the price drops at the farm level there is a correction below the balance line which affects the adjustment back to the long-term balance of magnitude 0.14 when prices decrease at the retail level. So that the decline in potatoes prices at the farm level does not affect the decline in prices at the retail level. The price of potatoes increases at the farm level has an influence on the increase of potato prices at the retail level and is transmitted faster than when prices decrease at the farm level. Therefore, there is a common response due to price changes that occur in the farm level to the formation of potato prices at the retail level when prices decrease or increase. 
Wald test in Table 5 shows potatoes price at retail level and At the farmer level have transmission price coefficient increases at farmer level of $\mathrm{ECT}^{+}{ }_{(1)}$ and It is not identical coefficient of transmission price at retail level of $\mathrm{ECT}_{(2)}$ and significant at Ftest 0.001185 with a probability value of 0.9727 , which means that transmission asymmetry price on the short and long term has positive shock and negative shock at the same response.

TABLE 5. WALD TEST ON TRANSMISSION COEFFICIENT OF POTATOES PRICE INCREASES AT FARMER LEVEL WITH THE COEFFICIENT OF TRANSMISSION PRICE AT RETAIL LEVEL ON JANUARY 2009 TO DECEMBER 2013 IN BANDUNG REGENCY

\begin{tabular}{lcc}
\hline Wald Test & Critical Value & Probability \\
\hline T test & 0.034431 & 0.9727 \\
F Test & 0.001185 & 0.9727 \\
Chi-Square & 0.001185 & 0.9725 \\
\hline
\end{tabular}

Source: Authors' calculation

TABLE 6. PRICE TRANSMISSION ELASTICITY OF POTATOES PRICES IN SHORT-TERM AND LONG-TERM ON JANUARY 2009 TO DECEMBER 2013 IN BANDUNG REGENCY

\begin{tabular}{|l|l|l|l|l|}
\hline Commodity Price & Transmission Direction & Variables & Short-Term & Long-Term \\
\hline Potatoes & One-way asymmetric direction from & $\Delta \mathrm{PF}_{+}^{+} \mathrm{EC}_{(-1))}$ cointegration occur ${ }^{*}$ & $0.7752\left({ }^{*}\right)$ & $\begin{array}{l}1.0085\left({ }^{*}\right) \\
-0.21\end{array}$ \\
& & & $\left.*^{*}\right)$ \\
\hline
\end{tabular}

note: *level of significant at alpha $5 \%$

Source: Authors' calculation

Asymmetric increase in potato prices by $1 \%$ at the retail level has an effect of $77.52 \%$ increase in prices at the farm level in the short term. Asymmetrical changes in one direction are positive, reflecting the elasticity of price transmission that is inelastic to the commodity potato at the farm level $\left(\Delta \mathrm{PF}_{\mathrm{t}}^{+}\right)$.

The $\mathrm{ECT}_{\mathrm{t}-1}$ long-term equilibrium price adjustment coefficient of 1.0085 means that an increase in farmer's price change of $1 \%$ will increase the increase in the price of potatoes at the retail level by 100.0085 percent.

The formation of equilibrium prices in the long run is shown by the results of the cointegration test of -0.21 . It shows that there is a short-term price correction at the farm level affecting the transmission of long-term equilibrium prices that reflect price adjustments at the retail level (Simioni, 2013).

\section{Formation of price balance for long term commodity potatoes}

Nonlinear threshold behavior formulates long-term price balance movements to determine the chance of a price adjustment transition increases from retail level to farmer level price $\left(\mathrm{P}_{12}\right)$ or transition price movement down $\left(\mathrm{P}_{21}\right)$ using Markov Switching Model (Enders and Siklos, 2001). 


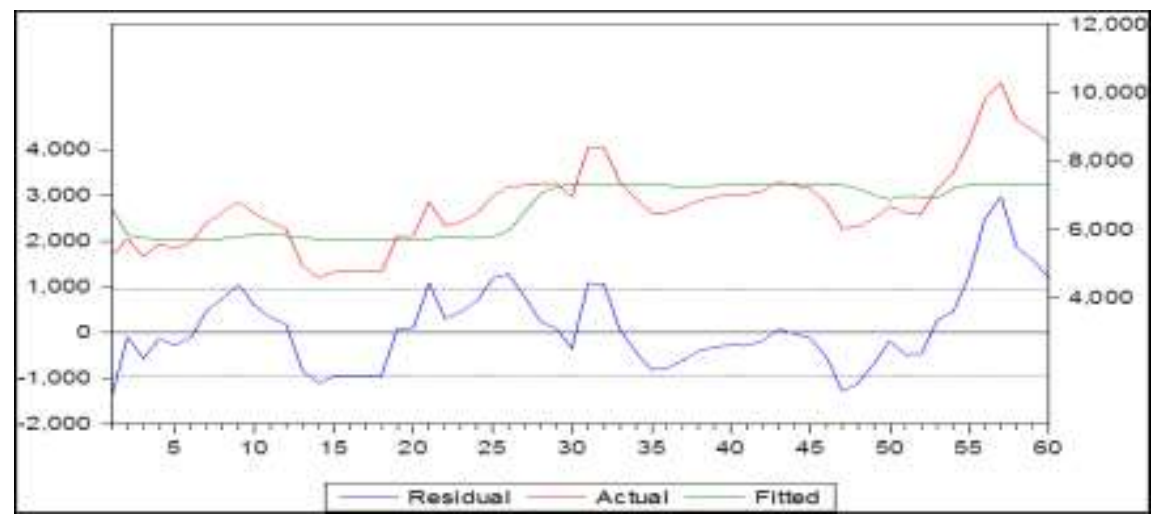

FIGURE 3. THE TRANSITION TO THE LONG-TERM BALANCE OF POTATO COMMODITY PRICE CHANGE IN RETAIL

The threshold behavior of potato price balance at the farmer level shown by the Green Line and it is above the price balance line in the range of IDR 1,800 when the price drops in the regime 1 and IDR 8,000 when the price in the regime 2 is in the pattern of real price movements.

TABLE 7. PROBABILITY TRANSITION OF POTATOES PRICE REGIME 1 TO PRICE REGIME 2 AT FARM LEVEL TO RETAIL LEVEL ON POTATOES COMMODITY ON JANUARY 2009 TO DECEMBER 2013 IN BANDUNG REGENCY

\begin{tabular}{lr}
\hline Variables & Coefficient \\
\hline Price Regime 1 $\left(\mathrm{P}_{11}\right)$ & \\
$\mathrm{C}$ & $5.597,33\left(^{*}\right)$ \\
Price Regime 2 $\left(\mathrm{P}_{21}\right)$ & $7.963,32\left(^{*}\right)$ \\
$C$ & \\
Common & $6.77\left(^{*}\right)$ \\
LOG(SIGMA) & $3.83\left(^{*}\right)$ \\
Transition Matrix Parameters & $-4.19\left(^{*}\right)$ \\
$P_{11}-C$ &
\end{tabular}

Note: Probability Transition of Low Price Farm at Regime $1\left(P_{11}\right)$ to Regime $2\left(P_{21}\right)$

Source: Authors' calculation

Potatoes farmers as price receivers also enjoy incentives from the establishment of a potato retail price in the range of $-4.19<0<3.83$ both at the time the price of potatoes harvest drops in one growing season and at the time the price of the potato harvest increases, although a large portion of the incentive is still owned by the potato merchant. The price of the potato retail in Caringin market in $\mathrm{t}$ period was formed based on the change in down price at regime 1 of IDR 5,597 and the increase price at regime 2 by IDR 7,963. 


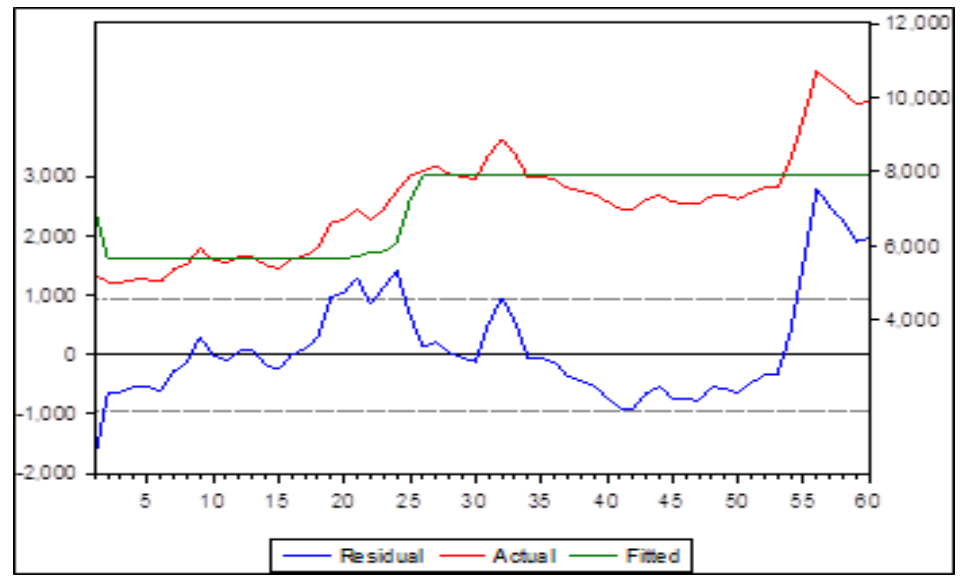

FIGURE 4. TRANSITION POTATOES PRICE CHANGE IN LONG-TERM BALANCE

Potatoes price balance in the long-term contains a pattern of asymmetric price transmission in one way from the level of farmers to the retail level. There is correction in the short-term price of prices. It dropped below the balance price of IDR 8,000 (green line) in the range of IDR 6,000 (blue line) and there is a margin about IDR 2,000.

The spatial difference in rural areas, whereas potatoes farming located with potatoes retail market in Bandung City, does not establish spread potato price margins. Potatoes price reductions at the retail level were slowly responded by prices at the farm level. Potatoes price difference occurs when the price drop is "saved" to reach the balance price at the next price period. Cyclical behavior like this in price theory is called a random price behavior or called the threshold behavior (Takayama and Judge, 1971).

TABLE 8. THE EMPIRICAL RESULT OF TRANSMISSION PRICE WITH FARMER PRICE AS DEPENDENT USING VON CRAMON METHOD ON JANUARY 2009 TO DECEMBER 2013 IN BANDUNG REGENCY

\begin{tabular}{|c|c|c|}
\hline Variables & Coefficient & Prob. \\
\hline $\bar{C}$ & 0.035 & 0.0788 \\
\hline Farm Price ${ }_{t-1}^{-1}$ & 0.24 & 0.4780 \\
\hline Farm Price ${ }_{t-1}^{+}$ & 0.09 & 0.6570 \\
\hline Retail Price- & 0.29 & 0.1306 \\
\hline Retail Price $^{+}$ & 0.12 & 0.3731 \\
\hline Retail Price $_{t-1}^{-}$ & 0.13 & 0.5246 \\
\hline Retail Price $^{+}{ }_{\mathrm{t}-1}$ & 0.09 & 0.5114 \\
\hline $\mathrm{ECT}_{2+-1}^{-i}$ & 0.04 & 0.5727 \\
\hline $\mathrm{ECT}_{2}{ }^{+}+1$ & -0.18 & 0.0931 \\
\hline
\end{tabular}

Source: Authors' calculation, ECT2 is price correction in long-term

When prices are at the farm level as dependent, the value of price adjustment at the retail level drops in the long-run is indicated by a price adjustment variable down at the retail level in the long-run $\mathrm{ECT}_{(2)-t-1}$ with a value of 0.04 different enough with a value adjustment the price increases at the long-term retail level indicated by the variable ECT2 ${ }_{\mathrm{t}-1}^{+}$of- 0.18 which means that a price transmission asymmetry occurs when the price of potatoes at the retail level increases or decreases is transmitted to price adjustments at the farm level.

Potatoes traders at the retail level still maintain margins when potatoes prices go down at the probability transition range of -0.18 to -0.2 . They still receive incentives from trading 
potatoes so that they remain staying in the potatoes market. In the short-term, the asymmetry of price transmission is determined by how much margin retailers receive that is derived from the demand for potato prices at the farm level.

The managerial ability of potato growers who have a narrow land area of less than 1 hectare in anticipation of transmission of seasonally price goes up or price goes down in the long run is actualized through the decision to sell harvests in groups with other potato farmers based on Caringin wholesale market reference prices. A casual mode of communication such as snacking and drinking coffee in local stall is used by smallholder farmers by obtaining information on the price of potatoes at Caringin market.

\section{CONCLUSION}

Testing Price transmission asymmetry in the market structure of the competition against the monthly data commodity prices potatoes at the farmer level and the retail level is conclusively proven with a confidence level of $5 \%$ and $10 \%$, at the farm price as variable dependent. There is asymmetric price transmission in the short and long term. The asymmetric price transmission occurs on the price-down adjustment at the corrected farm level to be priced up at the retail level in the long run.

Potatoes are relatively longer stored in fresh form, have a longer price adjustment speed when the transmission price increases at the farm level to the retail level. Conversely, potatoes when prices drop at farm levels are more rapidly transmitted at the retail level.

Formation of potato price balance based on short-term price correction at the farmer level. Transition changes to the threshold price up and price low of potatoes, there is a chance of transmission transition price adjustments from prices down at the farmer level before achieving a long-term increasing price balance at the retail level.

Policy interventions are thus required to influence the behaviour of potatoes price threshold at the retail level through potatoes quality size and reduce transaction costs at retail level, for example through a producer cooperative consisting of farmers and potato retailers.

Price policy incentives at the farm level by policy direction to the purchase based on quality. Also, price incentives based on spatial difference between rural and urban so that the farmers enjoy the results of the quality harvest.

Farmers strategy to sell potatoes to traders in a group way, is expected to get bigger selling results rather than selling themselves directly to the merchant. Generally, the location of the potatoes farm that is far from the highway access causes the cost of transport is quite high when borne by the farmer, so the choice of selling potatoes harvest in groups makes the cost of transport can be borne together in the group. Farmers and traders need to get a portion of important policy-making roles to improve the agribusiness management skills of farmers and retail traders in cooperative containers. 


\section{ACKNOWLEDGEMENT}

This article is part of dissertation research results, which funded by Directorate of Higher Education Scholarship in 2012 to 2015 fiscal years.

\section{REFERENCES}

Akhmadi, Siregar H, Hutagaol MP. 2016. Pengembangan Agribisnis Sebagai Strategi Penanggulangan Kemiskinan Di Perdesaan.Jurnal Manajemen \& Agribisnis, Vol. 13 No. 3, November 2016:pp.240-253. Nomor DOI: 10.17358/JMA.13.3.240

Andriyanto F, Setiawan B, Riana FD. 2013 Dampak Impor Kentang Terhadap Pasar Kentang di Indonesia. HABITAT 59(1), 59-70.

Boyd, MS dan Brorsen, BW. 1988. Price Asymmetry in the U.S. Pork Marketing Channel, North Central Journal of Agricultural Economics 10,103-109.

Enders, W dan P.L, Siklos. 2001. Cointegration and Threshold Adjustment. Journal of Business and Economic Statistics 19(2), 166-176

Hamilton, JD. 1989. A New Approach to the Economic Analysis of Nonstationary Time Series and the Business Cycle, Econometrica 57(2), 357-384.

Houck, J.P. 1977. An Approach to Specifying and Estimating Nonreversible Functions, American Journal of Agricultural Economics 59,570-572.

Ikechi K, Agbugba dan Obi, A.2013.Market Structure, Price Formation and Price Transmission for Wood Charcoal in Southeastern Nigeria. Journal of Agricultural Science, 5(10), 77-86.

Karantininis, K. et al.2011. Price transmission in the Swedish Pork Chain: Asymmetric non linear ARDL. Paper presented at the EAAE 2011 Congress, Zurich, Switzerland

Kinnucan HW, Forker OD. 1987. Asymmetry in Farm-Retail Price Transmission for Major Dairy Product. American Journal of Agricultural Economics 69(2), 285-292.

Krogerus, M dan Tschäppeler, R.2012.The decision book: fifty models for strategic thinking; translated by Jenny Piening-1st American ed.W.W.Norton Special \& Company Ltd. New York.

Meyer, J. dan S. von Cramon-Taubadel. 2004. Asymmetric price transmission: a survey.Journal of Agricultural Economics 55,581-611.

Peltzman, S. (2000). Prices Increase Faster than They Decrease, Journal of Political Economy 108(3), 466-502.

Pindyck, RS. dan Daniel LR. 2005. Microeconomics. Sixth Edition. International Edition. Pearson Prentice Hall. Pearson Education International. USA.

Sherman, J dan Weiss, A. 2012. Price Response, Asymmetric Information, and Competition. Ph.D. dissertation in economics, Bar-Ilan University.

Simioni, M; Gonzales, F; Guillotreau, P dan LL, Grel. 2013. Detecting Asymmetric Price Transmission with Consistent Threshold along the Fish Supply Chain. Canadian Journal of Agricultural Economics 61, 37-60 
Takayama, T. dan Judge, GG. Spatial and Temporal Price and Allocation Models (Amsterdam, The Netherlands: North Holland Publishing Co., 1971).

Timmer, CP. 1986. "Getting Prices Right: The Scope and Limits of Agricultural Price Policy". Ithaca, N.Y.: Cornell University Press.

Tsay, RS. 1989. Testing and Modeling Threshold Autorgressive Process. Journal of the American Statistical Association 84(405), 231-240.

Verela, G, Carrol-Aldaz, E dan Iacovone, L.2013.Determinants of market integration and price transmission in Indonesia. Journal of South East Asian Economies 30(1), 19-41

Von Cramon-Taubadel S dan Loy JP. 1999. The Identific ation of Asymmetric Price Transmission Processes with Integrated Time Series. Jahrbücher für Nationalökonomie und Statistik 218(1-2), 85-106. https://doi.org/10.1515/jbnst1999-1-206

Weldegebriel, HT, Wang, X, Rayner, AJ. 2012. Price transmission market powerand industry technology: a note. China Agricultural Economic Review 4(3), 281-299

Zapata, HO dan Gauthier, WM. 2003. Threshold Models in Theory and Practice. Department of Agribusiness and Agri-Economics, Louisiana State University, Baton Rouge, Louisiana. 